\title{
65. An Aberrant Type of the Fusulinidae from the Kitakami Mountainland, Northeastern Japan.
}

\author{
By Shôshirô Hanzawa. \\ Institute of Geology and Palaeontology, Tohoku Imperial University, Sendai. \\ (Comm. by H. YABE, M.I.A., July 12, 1938.)
}

\section{Introduction}

The purpose of the present article is to describe an aberrant type of the Fusulinidae found in the Permian formation, which is exposed at three widely separated localities in the Kitakami Mountainland, Northeastern Japan. As the fossil foraminifera now in question are imbedded in indurated limestone or sandstone and inseparable from the matrix, the present study was carried by means of microscopical examinations of the thin slices of the rocks. The present fusulinid foraminifera from every locality are not accompanied by any other forms of foraminifera, except smaller foraminifera assignable to the genus Cribrogenerina in the limestone from Ôsimidu, Nisikôri-mura, Rikuzen Province.

The first discovery of the present fossils has been made more than ten years ago, by Prof. Yabe, who collected a pebble of calcareous sandstone in the river-bed of the Yahagi river, as he noticed peculiar impressions on the weathered surface of the pebble. Namely, the weathered surface of the pebble is scattered by many tiny curved grooves, which are such as we could make by impressing the tips of our finger-nails on the surface of a lump of soft clay. Microscopical examinations of thin slices of the pebble proved that these tiny curved impressions were produced by weathering of tests of an aberrant type of the Fusulinidae, which are imbedded in the rock. Although the original source, from which the pebble mentioned above was derived has not yet been ascertained, it is surmised that this sandstone should probably belong to the Maiya group, which is exposed along the course of the Yahagi and Permian in age.

Later, the similar type of the fusulinid foraminifera has been found by the late Mr. Y. Nunose and Mr. Y. Onuki from Ôsimidu, Nisikôrimura, Tome-gun and Sakamotozawa, Hikoroiti-mura, Kesen-gun, Rikuzen Province respectively.

The present aberrant type of the fusulinid foraminifera resembles the genus Codonofusiella described by C. O. Dunbar and J. W. Skinner" from the Permian of Texas in general configuration. Namely, it is closely coiled in the juvenility as ordinary fusulinids, while the test in maturity becomes uncoiled. This type is supposed as an aberrant offshoot of the genus Triticites. Because, its spirotheca possesses a coarse

1) Dunbar, C. O. and Skinner, J. W.: Permian Fusulinidae of Texas, The Geology of Texas, vol. 8. The University of Texas, Bull. 3701, 1937, pp. 606-607. 
alveolar structure, while those of Codonofusiella is missing of it, moreover, the septa are straight along near the tops and fluted along the bases, and chomata present on either side of the aperture in each septum in the coiled part of the test. I propose a new generic name Nipponitella for the aberrant type of the Fusulinidae. In the present material found from three different localities, I discriminated three species. Among them, I choose the specimens found from Sakamotozawa as the genotype and name them as Nipponitella explicata.

Descriptions

Genus Nipponitella n. gen.

Genotype Nipponitella explicata n. sp.

Test moderate in size, nearly semicircular in outline in axial view; bimorphic, the juvenility fusiform or subcylindrical, consisting of a spherical proloculum and several closely coiled whorls, the test in maturity suddenly opening out as an auricle-like terminal flange; spirotheca consisting of a thin tectum and a thick keriotheca with coarse alveoli; septa in the coiled stage straight in the upper half, while regularly and intensely fluted along the base so as to make cuniculi ${ }^{1)}$ of the septa as in the genus Parafusulina, the septa intensely fluting in the terminal flange, so that the folds reach to the tops of the septa and their recurved lower parts making the ventral walls of the terminal flange, while its dorsal wall is continued with the spirotheca of the earlier whorls and having a keriotheca; aperture in the coiled part slit-like, situated at the middle part of the base of each septum, the apertural features in the terminal flange not confirmed in the present material ; chomata present on either side of the apertures.

Occurrence.-The Maiya group, Permian in age, in the Kitakami Mountainland, Northeastern Japan.

\section{Nipponitella explicata n. sp.}

\section{Figures 8-16.}

Test moderate in size, bimorphic; the juvenility subcylindrical with blunt poles, attaining $6 \mathrm{~mm}$ in axial length and $1.6 \mathrm{~mm}$ in height, consisting of a spherical proloculum $100-120 \mu$ in diameter and seven closely coiled whorls immediately succeeding the proloculum; in maturity the test suddenly uncoiled and developing as an auricle-like terminal flange $4 \mathrm{~mm}$ in width and $1 \mathrm{~mm}$ in thickness; spirotheca composed of a thin tectum and a keriotheca $80 \mu$ in maximum thickness, the keriotheca being rather coarse in texture, 20 alveoli counted in a space of $500 \mu$; septa straight near the tops and regularly and so intensely fluted near the bases as to make cuniculi in juvenility, and intensely fluted so that the folds reach the tops of the septa in the terminal flange, the recurved ends of the septa making the floors of the chambers in the terminal flange; aperture slit-like in the middle part of the base of each septum; chomata present on either side of the apertures.

1) Dunbar, C. O. and Skinner, J. W.: loc. cit., p. 535. 
No. 7.] An Aberrant Type of the Fusulinidae from the Kitakami Mountainland. 257

Measurements of the juvenility of Nipponitella explicata n. sp.

\begin{tabular}{l|c|c|c|c}
\hline Whorls & $\begin{array}{c}\text { Height of } \\
\text { whorls }\end{array}$ & $\begin{array}{c}\text { Height of } \\
\text { chambers }\end{array}$ & Axial length & $\begin{array}{c}\text { Number of } \\
\text { septa }\end{array}$ \\
\hline I & $200 \mu$ & $20-60 \mu$ & $250 \mu$ & 8 \\
II & $300 \mu$ & $40-80 \mu$ & $500 \mu$ & 11 \\
III & $500 \mu$ & $100 \mu$ & $1,000 \mu$ & 13 \\
IV & $750 \mu$ & $120 \mu$ & $1,600 \mu$ & $15-17$ \\
V & $1,120-1,210 \mu$ & $160-220 \mu$ & $2,100 \mu$ & 21 \\
VI & $1,480-1,500 \mu$ & $140-220 \mu$ & $3,000 \mu$ & 24 \\
VII & $1,900 \mu$ & $220-300 \mu$ & $6,000 \mu$ & 24 \\
\hline
\end{tabular}

Occurrence.-This species is found in a limestone of the Maiya group (Permian) developed in Sakamotozawa, Hikoroiti-mura, Kesengun, Rikuzen Province. Mr. Y. Onuki, collector. The cotypes is in the Institute of Geology and Palaeontology, Tôhoku Imperial University, Sendai, Japan. Rg. No. 21847.

Nipponitella auriculla n. sp.

Figures 1, 2.

The second species of the present new genus is distinguishable from the preceding species, although its sufficient oriented sections have not been obtained. Because the juvenility of the present species reveals fusiform and small size, ca. $2 \mathrm{~mm}$ in axial length and ca. $0.3 \mathrm{~mm}$ in height. It consists of a spherical proloculum $200 \mu$ in diameter and two tightly coiled whorls, the first and second whorls are $300 \mu$ and $600 \mu$ in height respectively. The deploy of the whorl commences suddenly at the third whorl, the terminal flange attains $6 \mathrm{~mm}$ in width and $0.8 \mathrm{~mm}$ in thickness. The interval between two adjacent septa in the terminal flange is usually $250-350 \mu$, while near the poles of the test, it is squeezed as narrow as $100 \mu$. The spirotheca is relatively thick and it appears as a dark line under the microscope, but the alveolar structure is indiscernible. The obscurity of the spirothecal structure would depend upon the fossilization.

Occurrence.-This species is found in a limestone of the Maiya group from Ôsimidu, Nisikôri-mura, Tome-gun, Rikuzen Province and accompanied by Cribrogenerina? sp. The late Mr. Y. Nunose, collector. The figured specimens are in the Institute of Geology and Palaeontology, Tôhoku Imperial University, Sendai, Japan. Rg. No. 21845.

\section{Nipponitella expansa n. sp.}

Figures 4-7.

Although the thin slices of the pebble of the Yahagi river now at my disposal do not present axial sections of the foraminifera, I discriminated the third species of the present new genus. The juvenility of this species consists of a spherical proloculum, 100-140 $\mu$ in diameter and three or four closely coiled whorls, the height of the first, second, and third whorls are $300 \mu, 500 \mu$, and $1,200 \mu$ respectively. The un- 
coiling of the test suddenly takes place at the fourth or fifth whorl, as a result, a terminal flange $3.3 \mathrm{~mm}$ or more wide and $0.8 \mathrm{~mm}$ thick is produced. The structure of the keriotheca is coarse, 21-22 alveoli are in a space of $500 \mu$. This species is closely related with Nipponitella auricula, but in the former, the septal interval is usually $250 \mu$ wide and not so much squeezed in any part of the former species as in the latter.

Occurrence.-The exact locality and horizon are unknown as already

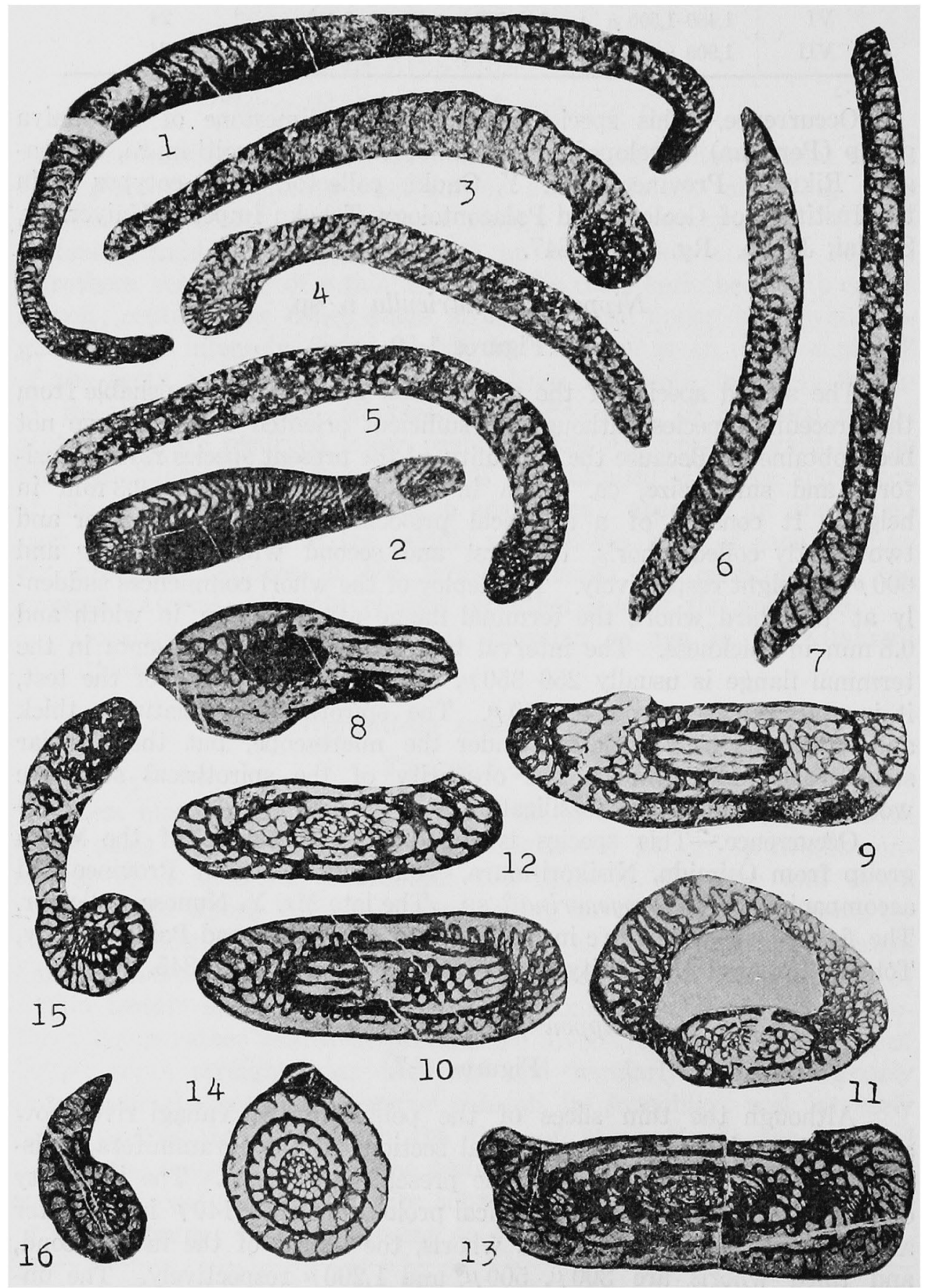


No. 7.] An Aberrant Type of the Fusulinidae from the Kitakami Mountainland. 259

mentioned. Yahagi-mura, Kesen-gun, Rikuzen Province. Prof. H. Yabe collector. The figured specimens are in the Institute of Geology and Palaeontology, Tôhoku Imperial University, Sendai, Japan. Rg. No. 21486.

\section{Explanation of Figures.}

Figs. 1, 2. Nipponitella auricula n. sp. Ôsimidu, Nisikori-mura, Tome-gun, Rikuzen Province. I. G. P.S. J. 21485.

Fig. 1. An oblique section passing through the proloculum.

Fig. 2. An oblique section of the extremity of the terminal flange.

Figs. 3-7. Nipponitella expansa n. sp. Yahagi-mura, Kesen-gun, Rikuzen Provinee. I. G. P.S. J. 21486.

Figs. 3, 5. Sagittal sections passing through the proloculum.

Fig. 4. An excentric sagittal section.

Fig. 6. An axial section of the terminal flange.

Fig. 7. An oblique section of terminal flange.

Figs. 8-16. Nipponitella explicata n. sp. Sakamotozawa, Hikoroiti-mura Kesen-gun, Rikuzen Province. I. G. P. S. J. 21487.

Figs. 8-10. Tangential sections not cutting across the terminal flange, showing the plan of septal flutings. The septa are straight or minutely undulated near the tops, while the basal sutures of the septa run at right angles to the axis of coiling of the test defining cuniculi.

Fig. 11. A tangential section cutting across both the terminal flange and the juvenility.

Fig. 12. An oblique section of the juvenility passing through the proloculum.

Fig. 13. An axial section of the juvenility and a part of the terminal flange.

Fig. 14. An excentric sagittal section of a specimen not yet producing the terminal flange.

Figs. 15, 16. Excentric sagittal sections.

(All figures are enlarged ten times natural size). 